\title{
CHEMOKINE RECEPTORS
}

\author{
Agáta Gibejová
}

Department of Immunology, Medical Faculty of Palacký University, I. P. Pavlova 6, 77520 Olomouc, Czech Republic

Received July 14, 2000

Key words: Chemokines / Chemokine receptors / Polymorphisms / Knockout mice / Function in vivo

Chemokines mediate their multiple effects by binding to a variety of specific receptors, that comprise a subfamily of rhodopsin-like, 7-transmembrane domain receptors, coupled to $G$ proteins. Some of these receptors serve as coreceptors for HIV, some of them could be expressed as markers for T lymphocyte functional differentiation. This review aims at summarising data on chemokine receptors, their function in vivo, their target cells and it also mentions association of chemokine receptor polymorphisms with human disease.

\section{THE CHEMOKINE RECEPTOR FAMILY}

Chemokines constitute a large family of small glycoproteins that regulate diverse biological processes, including leukocyte trafficking, angiogenesis, hematopoiesis, and organogenesis ${ }^{1}$.

Chemokines mediate their activities by binding to the receptors that comprise a subfamily of rhodopsinlike, 7-transmembrane (7TM) domain receptors (also called serpentine receptors), $G$ protein-coupled receptors (GPCR); they signal mainly through Gi-type proteins ${ }^{1}$.

A general model for plasma membrane insertion of (7TM) proteins has been proposed, based on the distribution of conserved sequences and the known structure of rhodopsin. In this model, the receptor polypeptide is stitched into the membrane with the N-terminus extracellular domain, the C-terminus intracellular domain, and each of seven hydrophobic domains passing as $\alpha$ helices through the membrane ${ }^{2}$. This allows four extracellular, and four intracellular domains: a total of six loops (il-3 and el-3) connecting the seven (TM) domains, which form the (TM) core, and the free $\mathrm{N}$ - and $\mathrm{C}$-termini ${ }^{2}$. The receptors have a single polypeptide chain and have $25-80 \%$ of amino acid sequence identity to each other. These and other aspects of their structure indicate that chemokines and chemokine receptors each arose from common ancestors by repetitive gene duplication. Although chemokine receptors are similar to many GPCRs, they have unique structural motifs such as the amino acid sequence DRYLAIV in the second intracellular domain ${ }^{3}$.

Chemokines have two main sites for interaction with their receptors: the first lies in the amino-terminal region and the second is located in the exposed loop of the backbone between the second and the third cysteine $e^{4}$ The receptor initially recognises the chemokine loop region, and this interaction is necessary for the correct presentation of the amino-terminal region, which is then essential for the receptor triggering.
The chemokine signalling network is astonishingly complex, however the primary task of each receptor is conceptually simple, to bind a chemokine and to relay its signal to a heterotrimetric guanine nucleotide-binding regulatory protein (G $\alpha \beta \gamma$ protein). Agonist binding to the receptor catalyses the exchange of GTP for the GDP that is bound to the G $\alpha$ subunit and induces a dissociation/reassociation cycle of the $G \alpha$ and $G \beta \gamma$ subunits $^{5}$. The GTP-bound G $\alpha$ subunit and the G $\beta \gamma$ subunits then both independently activate downstream effectors such as adenylate cyclase, phospholipase $C \beta$, phosphatidylinositol-3-kinase and protein tyrosine kinases - allowing for cross-talk with the mitogen-activated protein kinase cascades (recently reviewed by Ward ${ }^{6}$ et al., 1998).

At present, 17 receptors have been identified. In agreement with the current chemokine nomenclature ${ }^{7}$, a name for a chemokine receptor starts with the abbreviation of its chemokine ligand subclass specificity (CC, $\mathrm{CXC}, \mathrm{XC}$, or $\mathrm{CX} 3 \mathrm{C}$ ), which is followed by " $\mathrm{R}$ " (for receptor) and then ends with a serial number. Thus, we have CCR1-10, CXCR1-5, XCR1 (the lymphotactin, $\mathrm{XCL} 1$, receptor), and CX3CR1 (the fractalkine, CX3CL1, receptor). The known chemokine receptors, together with their ligands and cell types for expression, are shown in the Table 1 . The table also illustrates "shared binding specificity" between many ligands and receptors. This "promiscuity" is real because it involves high-affinity interactions. Thus, a single chemokine may bind to several receptors, whereas a single chemokine receptor may transduce signals for several chemokines. This is one of the most intriguing features of the chemokine superfamily and may reflect their ability to regulate many different leukocyte subpopulations, especially in complex microenvironments such as acute or chronic inflammatory responses.

Some of novel chemokine receptor belong to "orphan" receptors. These are proteins where the ligand had not been identified. 
Table 1. Human chemokine receptors

Receptor (alternative names)

CC chemokine receptors family

CCR1
CCR2
CCR3

CCR4
CCR5
CCR6
CCR7
CCR8
CCR9
CCR10

CXC chemokine receptors family

CXCR1 (IL8RA)
CXCR2 (IL8RB)
CXCR3
CXCR4 (LESTR/fusin)
CXCR5 (BLR-1)

C chemokine receptors family

XCR1

CX3C chemokine receptor family

CX3CR1 (V28)

Ligands (alternative names)

MIP-1 $\alpha$, MCP-3, RANTES

Eotaxin-1, Eotaxin-2/MPIF-2,

TARC, MDC/STCP-1

MIP- $1 \alpha$, MIP-1 $\beta$, RANTES

MIP-3 $\alpha /$ LARC/Exodus-1

MIP-3ß/ELC/Exodus-3,

SLC/Exodus-2/6Ckine

I-309, TARC, MIP-1 $\beta$

TECK

CTACK

Main cells expression

Mo, T, NK, iDC, Neu

Mo, T (act) NK (act.)

$\begin{array}{ll}\text { MCP-1, MCP-2, MCP-3, MCP-4 } & \text { Mo, T (act) NK } \\ \text { MCP-2, MCP-3, MCP-4, RANTES, } & \text { Eo, Ba, T (Th2) }\end{array}$

Eotaxin-3, MIP-5/Lkn-1/HCC-2

T (Th2, Tc2), NK, iDC

Mo, T (Th1, Tc1), iDC

T, iDC (CD34+)

T, Mo, mDC

T (Th2/Tc2), Mo

Non-haematopoietic

$\mathrm{T}$

Fractalkine/neurotactin

$\begin{array}{ll}\text { IL-8, GCP-2, GRO } \alpha & \text { Neu } \\ \text { IL-8, GROs, NAP-2, ENA-78, } & \text { Neu } \\ \text { GCP-2 } & \\ \text { IP-10, MIG, I-TAC } & \text { T }(\text { Th1, Tc1) } \\ \text { SDF-1 } \alpha / \beta & \text { Widely expressed receptor } \\ \text { BCA-1/BLC } & \text { B }\end{array}$

Lymphotactin/SCM-1/ATAC

T, NK

T (Th1), NK, Mo

Miscellaneous chemokine receptor

DARC

IL-8, GRO $\alpha$, RANTES, MCP-1,

Erythrocytes

Abbreviations for cells: act., activated; Ba, basophils; DC, dendritic cells; iDC, immature DC; mDC, mature DC; DC (CD34+), DC derived from CD34+ cells in vitro; Eo, eosinophils; Mo, monocytes; Neu, neutrophils; NK, natural killer; Th, T helper; Tc, T cytotoxic

Abbreviations for chemokines: BCA-1, B cell-attracting chemokine 1; BLC, B-lymphocyte chemoattractant; 6Ckine, six-Cysteine chemokine; ENA-78, epithelial-cell derived neutrophil activating protein 78; ELC, EBI-1 ligand chemokine; GCP-2, granulocyte chemoattractant protein 2; GRO, growth-related oncogene; HCC-2, hemofiltrate CC chemokine 2; I-309, inducible 309; IL-8, interleukin 8; IP-10, interferon-inducible protein 10; I-TAC, interferon-inducible T-cell $\alpha$ chemoattractant; LARC, liver and activationregulated chemokine; MCP, monocyte chemotactic protein; MDC, macrophage-derived chemokine; MIG, monokine induced by interferon gamma; MIP, macrophage inflammatory protein; NAP-2, neutrophil-activating peptide 2; SDF-1, stromal cell-derived factor 1; SLC, secondary lymphoid tissue chemokine; STCP-1, stimulated T cell chemotactic protein; RANTES, regulated on activation of normal T cell expressed and secreted; TARC, thymus and activation-regulated chemokine; TECK, thymus-expressed chemokine

Adapted from the ref. $7-9\left(\right.$ index $\left.x^{2}\right)$ 


\section{CHEMOKINE RECEPTOR - LIGAND INTERACTIONS: THE FOUR GENERAL CATEGORIES}

\section{Promiscuous receptors}

The first class of chemokine receptors is that of the promiscuous receptor (Figure 1). It is defined here as a receptor which will bind chemokines of either CXC or $\mathrm{CC}$ classes. There is, however, only one example of this receptor to date, the erythrocyte chemokine receptor, name DARC (Duffy antigen receptor for chemokines). This receptor is expressed on erythrocytes and endothelial cells, where it was originally defined serologically as the Duffy blood group antigen and later pathologically as the invasin for the malaria-causing protozoan Plasmodium vivax ${ }^{10,11}$. Although DARC is structurally related to chemokine receptors it lacks the DRYLAIV motif in the second cytoplasmic loop, it is not coupled to heterotrimetric G-proteins and importantly does not elicit any detectable signal-transduction events ${ }^{10,11}$. The biological role for DARC is, therefore, unclear; it has been proposed to act as a "sink" for chemokines, which keeps their circulating levels low ${ }^{10,11}$.

\section{Shared receptors}

The second category is represented by the shared receptors, defined here as receptors which will bind to more than one chemokine within either the $\mathrm{CXC}$ or the CC class (Figure 1). There are three CXCR receptors (CXCR1-3), which bind to many of the CXC chemokines, and all CCR1-10 receptors, which bind to several of the CC chemokines.

\section{Specific receptors}

The third category is that of specific receptors, which seem to bind only one chemokine (Figure 1). These are the receptors such as XCR1 for lymphotactin (XCL1), CX3CR1 for fractalkine (CX3CL1), CXCR5 for BCA-1 (CXCL13), and CXCR4 for SDF-1 (CXCL12).

\section{Virally encoded receptors}

The fourth category of receptors are the virally encoded chemokine receptors (Figure 1). Although chemokines and chemokine receptors probably evolved as antimicrobial factors, many are exploited by infectious agents to facilitate the infection. Certain herpesviruses encode pirated chemokine receptors, including US28 (used by human cytomegalovirus), and ECRF3 (used by Herpesvirus saimiri) $)^{12,13}$. US28 binds the CC chemokine MIP-1 $\alpha$ (CCL3), MIP-1 $\beta$ (CCL4), RANTES (CCL5) and MCP-1 (CCL2) with similar affinity ${ }^{12}$. ECRF3 is selective for the CXC chemokines IL-8 (CXCL8), GRO $\alpha$ (CXCL1) and NAP-2 (CXCL7) ${ }^{13}$. US28 and ECRF3 functions have not been identified yet. Human cytomegalovirus and Herpesvirus saimiri could use chemokine receptors to control viral replication by regulating cell cycle progression of the host cell, or by inhibition apoptosis of the host cell ${ }^{12,13}$.

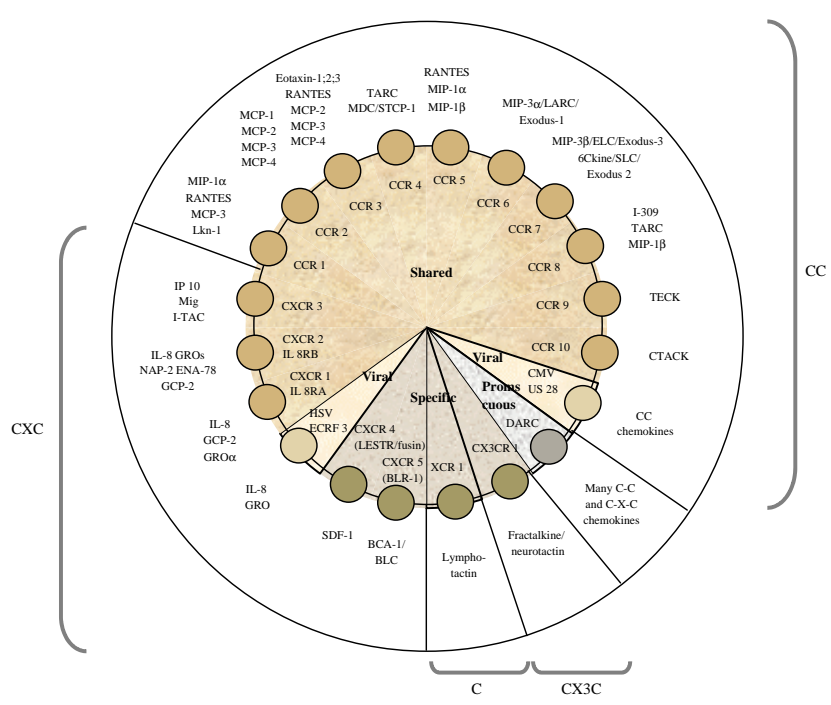

Fig. 1 The chemokine receptor overview

The catalogue of known chemokine receptors now includes 4 separate categories (adapted from the ref. 14).

\section{CHEMOKINE RECEPTORS AS MARKERS OF T LYMPHOCYTE DIFFERENTIATION}

Immune-mediated diseases can be classified as either Th1 (T helper 1) or Th2 (T helper 2) immunopathologies depending on the spectrum of cytokines produced by activated Th cells. Th1 cells produce mainly Interleukin (IL)-2, IFN- $\gamma$ and IL-12 whereas Th2 cells secrete IL-4, IL-5, IL-10 and IL-13 ${ }^{15}$. Th1 cells are the major players in the inflammation characterised by activated T cells and macrophages, and have been associated with diseases such as rheumatoid arthritis and delayed-type hypersensitivity reactions ${ }^{9}$. Th2 cells are involved in the responses leading to eosinophil and basophil recruitment and have therefore been implicated in the pathogenesis of allergic inflammatory diseases such as asthma and atopic dermatitis ${ }^{16}$.

Recently, it has been demonstrated that chemokine receptors are differentially expressed on naive Th1 and Th2 subsets, and their expression is modulated by cytokines. Naive $\mathrm{T}$ cells primarily express CXCR4 and thus are responsive to SDF-1 (CXCL12, stromal cellderived factor 1), a chemokine that has an important role in basal trafficking of naive $\mathrm{T}$ cells into lymphatic organs. Upon activation, T cells may express an array of chemokine receptors including CCR1, CCR2, CCR5, CXCR1 and CXCR $4{ }^{17}$. They thus become sensitive to inflammatory chemokines including MIP-1 $\alpha$ (CCL3), MIP-1 $\beta$ (CCL4), MCP-3 (CCL7) and RANTES (CCL5), which are thought to mediate T-cell trafficking to secondary lymph node structures and sites of inflammation ${ }^{6}$. Chemokines have an important role in the induction of inflammatory responses and are also central in selective the type of immune response (Th1 vs Th2). During 
bacterial or viral infections IP-10 (CXCL10), Mig (CXCL9), IL-8 (CXCL8) and I-TAC (CXCL11) production correlates with the presence of CD4 ${ }^{+}$Th1 cells ${ }^{17}$. In contrast, during allergic inflammatory responses eotaxin (CCL11), RANTES (CCL5), MCP-2 (CCL8), MCP-3 (CCL7) and MCP-4 (CCL13) are induced and the majority of the $\mathrm{CD}^{+}{ }^{+} \mathrm{T}$ lymphocytes are of the Th2type phenotype ${ }^{17}$. Characterisation of chemokine receptor expression on $\mathrm{T}$ lymphocytes suggests that this may be explained by the expression of CXCR3 and CCR5 predominantly on CD4 ${ }^{+}$Th1 cells ${ }^{18,19,20}$, whereas CCR3, CCR4, CCR8 (and perhaps CCR7) are restricted to CD4 ${ }^{+}$Th 2 cells ${ }^{19,20,21}$; the following molecules - CXCR4 and CCR2, and possibly also CCR1 - are expressed equally on both Th1 and Th2 cells, suggesting that these receptors as opposed to polarised (Th1 vs Th2) immune responses $^{18,19,23}$ (Figure 2).

These observations suggest that chemokine receptors expression on $\mathrm{T}$ cells together with tissue-specific chemokine expression are important factors in controlling the composition of lymphocyte infiltrates in different types of inflammatory pathologies.

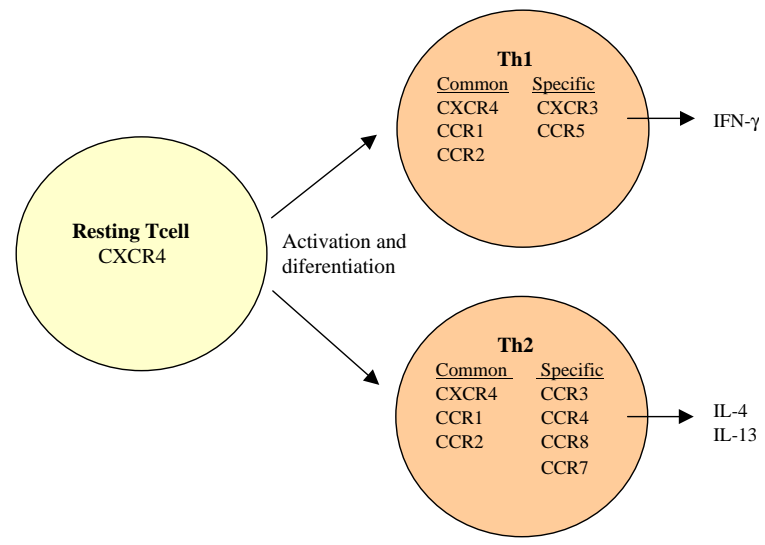

Fig. 2 The chemokine receptors as markers for T lymphocyte differentiation (adopted from the ref. 6).

\section{CHEMOKINE RECEPTORS AND HIV INFECTION}

Human Immodefficiency virus (HIV-1) is the aetiologic agent of AIDS which results from the destruction of $\mathrm{CD}^{+}$lymphocytes in infected individuals. The entry of HIV-1 into its targets cells is mediated by the viral envelope glycoproteins such as gp120, which binds the cellular receptor $\mathrm{CD} 4$, resulting in conformational change that exposes the V3 loop in gp120 and permits subsequent interaction with a chemokine receptor. The primary cellular receptor for all strains of HIV-1 is CD4 molecule ${ }^{24}$, but strain-specific chemokine receptors are required as coreceptors for fusion and entry ${ }^{25}$. CXCR4 is coreceptor for strains of HIV-1 that infect T-cell lines
(T-tropic strains ${ }^{25,26}$ and CCR5 is coreceptor for HIV-1 isolates that infect macrophages and activated $\mathrm{T}$ cells

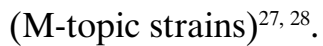

The importance of chemokine receptors in the pathophysiology of HIV infection became apparent when it was discovered that in an individual who was homozygous for a 32 bp deletion in the human CCR5 gene (CCR5 832 allele), a functional CCR5 protein cannot be synthesised, and such individuals are generally not found in HIV-1 positive cohorts ${ }^{29,}$ 30,31. Furthermore, in persons who are heterozygous for the mutation, the rate of progression of HIV-1 infection is slower than in those without the mutation ${ }^{29}$. CCR5 832 appears to have originated in northeaster Europe, and it occurs with an average allelic frequency of $10 \%$ in North American Caucasians; it is not found in native Asians and Africans. The frequency of the deletion mutation in the Czech population is no different from that in other European Caucasian populations ${ }^{32}$.

Many other polymorphisms, relevant to HIV infection, have been described in chemokine receptor genes (Table 2). Another much rarer mutation, CCR-m303 (which contains a premature stop codon at position 303) has also been reported to confer resistance to HIV-1 infection, and is presumed to act like $\delta 32^{33}$. The other two affect the rate of disease progression but may not affect susceptibility to initial infection, and their mechanism us unclear. One of these polymorphisms caused a conservative amino acid change in CCR2 (V64I, substitution of valine for isoleucine in the first transmembrane domain $)^{34}$ and the other is single-nucleotide polymorphism in the CCR5 promoter $(59029 \mathrm{~A} / \mathrm{G})$, which has a particularly strong affect and is very common in all racial groups tested ${ }^{35,36}$. Easterbrook ${ }^{37}$ et al. studied effects on HIV disease progression of other polymorphisms in the promoter region of CCR5 (positions 59353 and 59402), and found that $59353 \mathrm{C}$ allele was associated with a delayed progression.

Table 2. Polymorphisms in genes for CC chemokine receptors/HIV-1 coreceptors that alter susceptibility to HIV-1 infection and progression

\begin{tabular}{|c|c|c|c|c|c|}
\hline \multirow[t]{2}{*}{ Molecule } & \multirow[t]{2}{*}{ Polymorphism } & \multirow[t]{2}{*}{ Type } & \multicolumn{2}{|c|}{ Phenotypes } & \multirow[t]{2}{*}{ Mechanism } \\
\hline & & & $-/-$ & $+/-$ & \\
\hline \multirow[t]{5}{*}{ CCR5 } & CCR5 832 & Del & $\mathrm{R}$ & DP & Truncation \\
\hline & $\mathrm{m} 303$ & SNP & $\mathrm{R}$ & ND & Truncation \\
\hline & 59029 G/A & SNP & DP & - & ND \\
\hline & $59353 \mathrm{~T} / \mathrm{C}$ & SNP & DP & - & ND \\
\hline & 59402 G/A & SNP & - & - & ND \\
\hline CCR2 & V64I & SNP & ND & DP & ND \\
\hline
\end{tabular}

Abbreviations: -/-, homozygous for the given allele; +/-, heterozygous for the given allele; SNP, single nucleotide polymorphism; Del, deletion; R, HIV-1 resistance; DP, delayed progression to AIDS relative to other genotypes; ND, not determined

adapted from the references no. 1 and 37 


\section{CHEMOKINE RECEPTOR (CCR2, CCR5, CXCR1 AND CXCR2) GENE POLYMORPHISMS IN OTHER DISEASE}

Several studies have recently suggested association of certain chemokine receptor gene polymorphisms with other immunological diseases than HIV infection (Table 3).

Hall $^{38}$ et al. reported that individuals carrying the CCR5832 mutation are at reduced risk of asthma. This has not, however been confirmed in the Hungarian population, where CCR5 832 mutation in non-asthmatic but atopic children did not indicate a reduced risk ${ }^{39}$.

Petřek $^{40}$ et al. have shown an association between CC chemokine polymorphisms with pulmonary sarcoidosis in the Czech population. Their study has shown a decrease of the CCR2-64I allele, and a significant increase in the frequency of CCR5 $\delta 32$ allele in patients with sarcoidosis, CCR5 832 allele was associated with advanced disease. CC chemokine receptor polymorphisms should therefore be considered to be protective (CCR2-64I) or susceptibility (CCR5832) factors for the development of sarcoidosis. In agreement with the above findings, Hizawa ${ }^{41}$ et al., have reported that CCR2 polymorphism (CCR2-64I) is associated with decreased susceptibility to sarcoidosis in Japanese population.

A role of CCR2 and CCR5 gene polymorphisms in other immune-mediated diseases, such as multiple sclerosis (MS) and insulin-dependent diabetes mellitus (IDDM) was not confirmed ${ }^{42,43}$, however, a mutation in the CCR2 gene was postulated to possibly contribute to the susceptibility to the IDDM ${ }^{43}$.

The studies of association CCR5 832 with susceptibility to rheumatoid arthritis have yielded with quite conflicting results. Gómez-Reino ${ }^{44} \mathrm{et}$ al. suggested that a functional CCR5 receptor was required for the develop- ment of rheumatoid arthritis (RA) and this conclusion was based on the absence of the homozygous CCR5 832 deletion in patients with RA. The findings of Cooke ${ }^{45} \mathrm{et}$ al. were opposite: they have found two patients with homozygous CCR5 832 who had typical disease, and they concluded that blockade of CCR5 was unlikely to have therapeutic benefit. Another report on this topic by $\mathrm{Mack}^{46}$ et al., showed that the number of CCR5positive cells in the synovial fluid did not differ between the CCR5/CCR5 wild-type and the CCR5832/CCR5 heterozygous patients with RA. This finding suggests that a complete deficiency in the CCR5 receptor expression does not prevent the development of RA and other chemokine receptors (e.g., CCR2, CXCR3) may substitute for the CCR5 deficiency.

Renzoni ${ }^{47}$ et al. described 4 novel polymorphisms in the CXCR1 and CXCR2 genes. In the CXCR1 gene a novel polymorphism at nucleotide +2607 was found, resulting in a conservative amino acid substitution from serine to threonine at the 276 amino acid residue of the CXCR1 protein. In the CXCR2 gene 3 novel polymorphisms at nucleotide $+785(\mathrm{C}$ or $\mathrm{T}),+1208(\mathrm{~T}$ or $\mathrm{C})$, and +1440 ( $\mathrm{G}$ or $\mathrm{A})$ were identified, the first of which resulted in a silent codon change and the others were in the 3 untranslated area of exon. The authors ${ }^{47}$ studied an association between these polymorphisms and systemic sclerosis (SSc) and cryptogenic fibrosing alveolitis (CFA) and have reported an association between two polymorphisms in the CXCR2 gene (CXCR2 + 785 and CXCR2 +1208) and systemic sclerosis, independent of the presence of fibrosing alveolitis. This finding suggest a role for CXCR2 receptor in the pathogenesis of systemic sclerosis disease. No association was found between novel CXCR1 and CXCR2 polymorphisms and cryptogenic fibrosing alveolitis.

Table 3. Chemokine receptor CCR2, CCR5, CXCR1 and CXCR2 polymorphisms associated with different disease

\section{Asthma}

Sarcoidosis

Multiple sclerosis

IDDM

Rheumatoid arthritis

Systemic sclerosis - FASSc

CFA

HIV

$\begin{array}{lll}+,- & - & - \\ + & + & - \\ - & - & - \\ - & + & - \\ +,- & - & - \\ - & - & - \\ - & - & - \\ - & - & - \\ + & + & -\end{array}$

38,39
40,41
42
43
$44,45,46$
47
47
47
$29,31,33$,
$34,35,36,37$

Abbreviations: +, polymorphism is associated with disease; -, polymorphism is not associated with disease; CFA, cryptogenic fibrosing alveolitis; CCR5 32 , a 32-bp deletion in the CCR5 gene; CCR2-64I, a substitution mutation in the CCR2 gene; CXCR1 (+2607), polymorphism at nucleotide +2607 (G/C) in the CXCR1 gene; CXCR2 (+785), polymorphism at nucleotide $+785(\mathrm{C} / \mathrm{T})$ in the CXCR2 gene; CXCR2 $(+1208)$, polymorphism at nucleotide $+1208(\mathrm{~T} / \mathrm{C})$ in the CXCR2 gene; CXCR2 (+1440), polymorphism at nucleotide $+1440(\mathrm{G} / \mathrm{A})$ in the CCR2 gene; IDDM, insulin-dependent diabetes mellitus; FASSc, systemic sclerosis with fibrosing alveolitis; NFASSc, systemic sclerosis without fibrosing alveolitis 


\section{KNOCKOUT MICE AND EXPRESSION LEVELS AS TOOLS FOR TARGET VALIDATION}

Several chemokine and their receptors have been deleted in mice to address whether they a play a specific role in normal maintenance of the immune system or in diseased states where the immune balance is disturbed. There have already been some interesting results (Table 4).

Deletion of the CXCR2 homologue in mice caused impaired neutrophil recruitment upon infection, suggesting that CXCR2 antagonists may be useful in managing tissue damage during acute lung inflammation or sepsis ${ }^{48}$.

Deletion of either CXCR4 or its ligand SDF-1 (CXCL12) impaired bone marrow myelopoiesis, B cell lymphopoiesis, cerebellar development and gastric vascularization, and was lethal ${ }^{50,51,52}$. Gutierrez-Ramos ${ }^{65}$ studied of the in vivo role of CXCR4 and its ligand, SDF-1 (CXCL12), during allergic airway disease (AAD). This study has been limited by the fact that transgenic mice that have been made deficient in either molecule die early in life. The author ${ }^{65}$ presents data supporting that lungs from asthmatic patients as well as inflamed lung of mice subjected to a model of AAD show modulation of CXCR4 mRNA and protein expression during diseases. The blockade of CXCR4 in vitro lead to reduce the migration of both eosinophils and lymphocytes to the lung (BAL fluid and lung interstitium) by 50 and $60 \%$, respectively, indicating that CXCR4-mediated signals contribute to lung inflammation during allergic processes. CXCR4 and SDF-1 (CXCL12) have a critical role during $\mathrm{AAD}$ and the potential relevance of this receptor and its ligand in other inflammatory proces$\operatorname{ses}^{65}$.

BLR-1/CXCR5 knockout do not develop inguinal lymph nodes or B cell areas in secondary lymphoid tissues $^{53}$. The chemokine receptor BLR-1/CXCR5 is the first $\mathrm{G}$ protein-coupled receptor involved in the regulation of $B$ cell migration and localisation of these cells within specific anatomic compartments ${ }^{53}$.

Table 4. Function of chemokine receptors in vivo: phenotypes associated with targeted gene disruptions in mice and naturally-occurring inactivating mutations in humans

\begin{tabular}{|c|c|c|c|}
\hline Disrupted gene & Viable & Major phenotypes & References \\
\hline Mouse CXCR2 & Yes & $\begin{array}{l}\text { - Neutrophil and B cell expansion in blood, lymph nodes, spleen, and bone marrow } \\
\text { - Impaired neutrophil recruitment to intraperitoneal thioglycollate }\end{array}$ & 48 \\
\hline Mouse CXCR3 & Yes & _ Absence of acute or chronic cardiac allograft rejection & 49 \\
\hline Mouse CXCR4 & No & $\begin{array}{ll}\text { - } & \text { Ventricular septal defect } \\
\text { - } & \text { Impaired B cell lymphopoiesis } \\
\text { - } & \text { Impaired bone marrow myelopoesis } \\
\text { - } & \text { Impaired cerebellar development } \\
\text { - } & \text { Impaired gastric vascularization }\end{array}$ & $50,51,52$ \\
\hline Mouse CXCR5 & Yes & 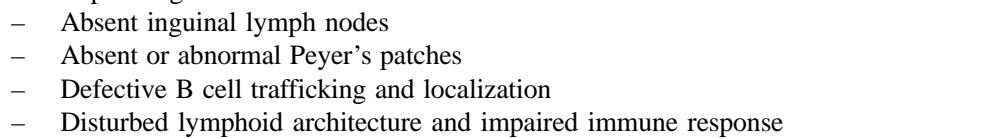 & 53 \\
\hline Mouse CCR1 & Yes & 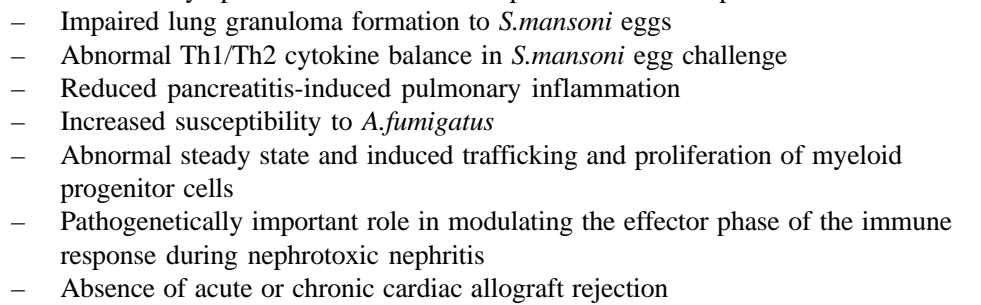 & $\begin{array}{l}49,54,55,56, \\
57\end{array}$ \\
\hline Mouse CCR2 & Yes & $\begin{array}{l}\text { - } \text { Reduced monocyte recruitment after intraperitoneal thioglycollate } \\
\text { - } \quad \text { Reduced size lung granuloma of elicited by PPD challenge } \\
\text { - } \quad \text { Increased susceptibility to Listeria } \\
\text { - } \quad \text { Decreased atherogenesis } \\
\text { - }\end{array}$ & $58,59,60$ \\
\hline Mouse CCR5 & Yes & $\begin{array}{ll}\text { - } & \text { Increased susceptibility to Listeria } \\
\text { - } & \text { Increased susceptibility to lipopolysaccharide endotoxemia } \\
\text { - } & \text { Increased humoral response to T cell-dependent antigenic challenge } \\
\text { - } & \text { Enhanced DTH reaction }\end{array}$ & 61 \\
\hline Mouse CCR7 & Yes & $\begin{array}{l}\text { - Delayed kinetics regarding the antibody response and lack contact sensitivity } \\
-\quad \text { Delayed type hypersensitivity reactions } \\
\text { - } \quad \text { Impaired migration of lymphocytes } \\
-\quad \text { Profound morphological alterations in all secondary lymphoid organs }\end{array}$ & 62 \\
\hline Human CCR5 & Yes & - Resistance to HIV-1 and AIDS & 29,30 \\
\hline Human Duffy & Yes & Resistance to $P$. vivax form of malaria & 63,64 \\
\hline
\end{tabular}


CCR1 deletion impaired the granulomatous response to Schistosoma mansoni eggs ${ }^{54}$, and decreased the severity of symptoms in models of multiple sclerosis. CCR1 knockout also have reduced pancreatitis-associated pulmonary inflammation ${ }^{55}$.

Deletion of CCR2 resulted in reduced monocyte and macrophage recruitment in response to inflammatory stimuli, and a decreased pathology in an atherosclerotic mouse model, suggesting a role for CCR2 antagonists in this disease ${ }^{60}$.

Macrophage and $\mathrm{T}$ cell accumulation in autoimmune and degenerative disorders is associated mainly, but not exclusive, with $\mathrm{CC}$ chemokines. There are also appear to be important in allergic inflammation in diseases such as asthma, based on the local presence of eotaxin (CCL11), MCP-3 (CCL7) and RANTES (CCL5); and expression of their shared receptor, CCR3, on eosinophils, basophils and Th2 cells, which accumulate at sites of allergic inflammation ${ }^{21,66,67}$.

In spite of the high level expression of CCR4 seen in vitro on Th2 polarised cells, in vivo, in an ovalbumin (OVA) model of inflammation (OVA induced lung inflammation, which is a predominantly Th2 driven disease), CCR4 does not appear to be required for development of a Th2 response ${ }^{68}$. Yet surprisingly, blockade of a CCR4 ligand, mouse MDC (CCL22), in the OVA model significantly reduces both bronchial hyperreactivity and leukocyte infiltration into the lung interstitium ${ }^{68}$. This suggests that there may be some compensatory mechanism for the loss of CCR4 in vivo or that a second receptor for MDC (CCL22) exists in mice ${ }^{68}$.

CCR5 expression is enhanced in the course of in vitro Mycobacterium tuberculosis infection and during active pulmonary tuberculosis ${ }^{69}$. CCR5 deletion have enhanced delayed hypersensitivity reactions and increased humoral responses to cell-dependent antigenic challenge ${ }^{61}$. Consistent with the notion that the chemokine system supports host defense, CCR1 and CCR5 knockout mice have increased susceptibility to inoculation with Aspergillus fumigatus and Listeria monocytogenes, respectively ${ }^{61}$. However, neither these nor any of the other chemokine/receptor knockout have increased susceptibility to spontaneous infection, indicating that sufficient redundancy exists within the system for baseline host defense ${ }^{1}$. Thus therapeutic "anti-chemokines" that are eventually developed (none has reached clinical trials yet) may profit from the specifity that certain chemokine appear to demonstrate in the amplification of pathologic inflammation versus the redundancy that appears to characterise chemokine regulation of immune function ${ }^{1}$.

CCR6 in interaction with MIP-3 $\alpha$ (CCL20) plays an important role in the trafficking of immature dendritic cells (DC) to chemokine production sites such as injured or inflamed peripheral tissues, where dendritic cells undergo maturation on contact with antigens ${ }^{70}$.

The deletion of the receptor CCR7 is embryonally not lethal. The phenotypical analysis will show whether CCR7 mutant mice represent a second animal model showing an in vivo function of chemokine receptors as regulators of homeostatic trafficking of lymphocyte subsets and functional compartmentalisation of secondary lymphoid organs ${ }^{71}$.

These results indicate complex and not yet understood roles for each of these molecules that extend the chemokine paradigm beyond simple chemotaxis and suggest a role for chemokines in modulating cytokine regulation of the inflammatory response. Analysis of gene expression patterns in knockout animals will lead to new insights into immune control in vivo.

Summarising the data from the different target validation approaches discussed above (monitoring expression levels, targeted gene disruption, use of blocking antibodies, modified chemokines) and tentatively infer pathogenic correlations relating various inflammatory diseases to particular chemokine receptors (Table 5).

Table 5. Involvement of chemokine receptors expressed on specific cell types in some inflammatory and infectious disease infered from different target validation.

\begin{tabular}{|c|c|c|c|c|}
\hline Receptor & Cell type & Validation basis & Disease & References \\
\hline CXCR1 & Neutrophil & Knockout mouse & Acute inflammation & $72,73,74,75$ \\
\hline CXCR2 & Neutrophil & Knockout mouse & Acute lung inflammation or Sepsis & 48 \\
\hline CXCR3 & Th1 T cell & Up-regulation of expression & Multiple sclerosis, Nephrotoxic nephritis & 56,76 \\
\hline CXCR4 & $\begin{array}{l}\text { T cells } \\
\text { Eosinophil }\end{array}$ & $\begin{array}{l}\text { Bicylam-type antagonists } \\
\text { The blockade of receptor }\end{array}$ & $\begin{array}{l}\text { HIV } \\
\text { Allergic airway disease }\end{array}$ & $65,77,78,79$ \\
\hline CCR1 & $\begin{array}{l}\text { T cells } \\
\text { Macrophage }\end{array}$ & $\begin{array}{l}\text { Knockout mouse } \\
\text { Met-RANTES } \\
\text { Up-regulation of expression }\end{array}$ & $\begin{array}{l}\text { Rheumatoid arthritis, Multiple sclerosis, } \\
\text { Nephrotoxic nephritis }\end{array}$ & $56,75,80$ \\
\hline CCR2 & $\begin{array}{l}\text { Monocyte } \\
\text { Macrophage } \\
\text { T cells }\end{array}$ & $\begin{array}{l}\text { Knockout mouse } \\
\text { MCP-1 knockout mouse }\end{array}$ & $\begin{array}{l}\text { Atherosclerosis, Nephrotoxic nephritis, } \\
\text { Granulomatous inflammation }\end{array}$ & $60,81,82$ \\
\hline CCR3 & $\begin{array}{l}\text { Eosinophil } \\
\text { Th2 T cell }\end{array}$ & $\begin{array}{l}\text { Up-regulation of expression } \\
\text { Eotaxin knockout mouse } \\
\text { Antibodies }\end{array}$ & Allergic disease (Asthma, Atopic dermatitis) & $83,84,85,86$ \\
\hline CCR4 & Th2 T cell & Antibodies & Allergic disease (Asthma, Atopic dermatitis), & 86 \\
\hline CCR5 & $\begin{array}{l}\text { Macrophage } \\
\text { Th1 T cell }\end{array}$ & $\begin{array}{l}\text { Knockout mouse } \\
\text { hCCR5 } \delta 32 \text { knockout } \\
\text { Up-regulation of expression }\end{array}$ & $\begin{array}{l}\text { HIV, Rheumatoid arthritis, Multiple sclerosis, } \\
\text { Nephrotoxic nephritis, Granulomatous } \\
\text { inflammation }\end{array}$ & $29,30,31,56,61,80$ \\
\hline
\end{tabular}




\section{CONCLUSIONS}

The spectrum of chemokine and their receptors roles has expanded since the first comprehensive review on this topic ${ }^{87}$. Nowadays, detailed understanding of chemokine receptor structure and signalling suggests new treatment modes for immune-mediated disease. Therapeutic targeting of chemokines and their receptors represents extension of their traditional understanding as proinflammatory mediators ${ }^{88}$ and has been already envisaged ${ }^{89}$. Moreover, recent suggestion that chemokine receptor gene polymorphism may play a role in susceptibility to immune disease, is a novel concept and brings new aspect to the complex field of chemokines and chemokine receptors.

\section{ACKNOWLEDGEMENTS}

The author wishes to thank to Dr. Martin Petřek for his guidance throughout preparing this manuscript. This work was supported in part by grant 14501107, Medical Faculty of Palacky University and by the Czech Ministry of Schools and Education (CEZ: J14/98: 15510002).

\section{REFERENCES}

1. Locati, M., Murphy, P. M. (1999) Chemokines and chemokine receptors: biology and clinical relevance in inflammation and AIDS. Annu. Rev. Med., 50, 425-440.

2. Murphy, P. M. (1996) Chemokine receptors: structure, function and role in microbial pathogenesis. Cytokine Growth Factor Rev., 7, 47-64.

3. Baggiolini, M., Dewald, B., Moser, B. (1997) Human chemokines: an update. Annu. Rev. Immunol., 15, 675-705.

4. Clark-Lewis, I., Kim, K. S., Rajarathnam, K., Gong, J. H., Dewald, B., Moser, B., Baggiolini, M., Sykes, B. D. (1995) Structureactivity relationships of chemokines. J. Leukoc. Biol., 57, 703-711.

5. Jung, S., Littman, D. R. (1999) Chemokine receptors in lymphoid organ homeostasis. Curr. Opin. Immunol., 11, 319-325.

6. Ward, S. G., Bacon, K., Westwick, J. (1998) Chemokines and T lymphocytes: more than an attraction. Immunity, 9, 1-11.

7. Zlotnik, A., Yoshie, O. (2000) Chemokines: a new classification system and their role in immunity. Immunity, 12, 121-127.

8. Mantovani, A. (1999) The chemokine system: redundancy for robust outputs. Immunol. Today., 20, 254-257.

9. Wells, T. N. C., Power, C. A., Proudfoot, A. E. (1998) Definition, function and pathophysiological significance of chemokine receptors. Trends Pharmacol. Sci., 19, 376-380.

10. Chaudhuri, A., Zbrzezna, V., Polyakova, J., Pogo, A. O., Hesselgesser, J., Horuk, R. (1994) Expression of the Duffy antigen in K562 cells. Evidence that it is the human erythrocyte chemokine receptor. J. Biol. Chem., 269, 7835-7838.

11. Hadley, T. J., Peiper, S. C. (1997) From malaria to chemokine receptor: the emerging physiologic role of the Duffy blood group antigen. Blood, 89, 3077-3091.

12. Gao, J. L., Murphy, P. M. (1994) Human cytomegalovirus open reading frame US28 encodes a functional beta chemokine receptor. J. Biol. Chem., 269, 28539-28542.

13. Ahuja, S. K., Murphy, P. M. (1993) Molecular piracy of mammalian interleukin-8 receptor type B by Herpesvirus saimiri. J. Biol. Chem., 268, 20691-20694.

14. Kunkel, S. L. (1999) Through the looking glass: the diverse in vivo activities of chemokines. J. Clin. Invest., 104, 1333-1334.
15. Mosmann, T. R., Coffman, R. L. (1989) TH1 and TH2 cells: different patterns of lymphokine secretion lead to different functional properties. Annu. Rev. Immunol., 7, 145-173.

16. Romagnani, S. (1994) Lymphokine production by human T cells in disease states. Annu. Rev. Immunol., 12, 227-257.

17. Rothenberg, M. E., Zimmermann, N., Mishra, A. Brandt, E., Birkenberger, L. A., Hogan, S. P., Foster, P. S. (1999) Chemokines and chemokine receptors: their role in allergic airway disease. J. Clin. Immunol., 19, 250-265.

18. Loetscher, P., Ugoccioni, M., Bordolli, L., Baggiolini, M., Moser, B. (1998) CCR5 is characteristic of Th1 lymphocytes. Nature, 391, 344-345.

19. Bonencchi, R., Bianchi, G., Bordignon, P. P., D Ambrosio, D., Lang, R., Borsatti, A., Sozanni, S., Allavena, P., Grray, P. A., Mantovani, A., Sinigaglia, F. (1998) Differential expression of chemokine receptors and chemotactic responsiveness of type $1 \mathrm{~T}$ helper cells (Th1s and Th2s). J. Exp. Med., 187, 129-134.

20. Mackay, C. R., Lanzavecchia, A., Sallusto, F. (1999) Chemoattractant receptor and immune responses. Immunologist, 7, 112-118.

21. Sallusto, F., Mackay, C. R., Lanzavecchia, A. (1997) Selective expression of the eotaxin receptor CCR3 by human T helper 2 cells. Science, 277, 2005-2007.

22. Zingoni, A., Soto, H., Hedrick, J. A., Stoppacciaro, A., Storlazzi, C. T., Sinigaglia, F., D Ambrosio, D., O Garra A., Robinson, D., Rocchi, M., Santoni, A., Zlotnik, A., Napolitano, M. (1998) The chemokine receptor CCR 8 is preferentially expressed in $\mathrm{Th} 2$ but not Th1 cells. J. Immunol., 161, 547-551.

23. Qin, S., Rottman, J. B., Kassam, N., Weinblatt, M., Loetscher, M., Koch, A. E., Moser, B., Mackay, C. R. (1998) The chemokine receptors CXCR3 and CCR5 mark subsets of T cells associated with certain inflammatory reactions. J. Clin. Invest., 101, 746-754.

24. Sattentau, Q. J., Weiss, R. A. (1988) The CD4 antigen: physiological ligand and HIV receptor. Cell, 52, 631-33.

25. Feng, Y., Broder, C. C., Kennedy, P. E., Berger, E. (1996) HIV-1 entry co-factor: functional cDNA cloning of a seven-transmembrane G-protein coupled receptor. Science, 272, 872-877.

26. Oberlin, E., Amara, A., Bachelerie, F., Bessia, C., Virelizier, J. L., Arenzana Seisdedos, F., Schwartz, O., Heard, J. M., Clark Lewis, I., Legler, D. F., Loetscher, M., Baggiolini, M., Moser, B. (1996) The CXC chemokine SDF-1 is the ligand for LESTR/ fusin and prevents infection by T-cell-line-adapted HIV-1. Nature, $382,833-835$.

27. Doranz, B. J., Rucker, J., Yi, Y., Smyth, R.J., Samson, M., Peiper, S., Parmentier, M., Collman, R. G., Doms, R. W. (1996) A dual-tropic, primary HIV- 1 isolate that uses fusin and the $\beta$ chemokine receptors CKR-5, CKR-3, and CKR-2b as fusion cofactors. Cell, 86, 1149-1159.

28. Alkhatib, G., Combadiere, C., Broder, C. C., Feng, Y., Kennedy, P. E., Murphy, P. M., Berger, E. A. (1996) CC CKR5: a RANTES, MIP-1alpha, MIP-1beta receptor as a fusion cofactor for macrophage-tropic HIV-1. Science, 272, 1955-1958.

29. Dean, M., Carrington, M., Winkler, C., Huttley, G. A., Smith, M. W., Allikments, R., Goedert, J. J., Buchbinder, S. P., Vittinghoff, E., Gomperts, E., Donfield, S., Vlahov, D., Kaslow, R., Saah, A., Rinaldo, C., Detels, R., O'Brien, S. J. (1996) Genetic restriction of HIV-1 infection and progression to AIDS by a deletion allele of the CKR5 structural gene: Hemophilia Growth and Development Study, Multicenter AIDS Cohort Study, Multicenter Hemophilia Cohort Study, San Francisco City Cohort, ALIVE Study. Science, 273, 1856-1862.

30. Liu, R., Paxton. W. A., Choe, S., Ceradini, D., Martin, S. R., Horuk, R., MacDonald, M. E., Stuhlmann, H., Koup, R. A., Landau, N. R. (1996) Honozygous defect in HIV-1 coreceptor accounts for resistance of some multiply-exposed individuals to HIV-1 infection. Cell, 86, 367-377.

31. Samson, M., Libert, F., Doranz, B. J., Rucker, J., Liesnard, C., Farber, C. M., Saragosti, S., Lapoumeroulie, C., Cognaux, J., Forceille, C., Muyldermans, G., Verhofstede, C., Burtonboy, G., Georges, M., Imai, T., Rana, S., Yi, Y., Smyth, R. J., Collman, R. G., Doms, R. W., Vassart, G., Parmentier, M. (1996) Resistance to HIV-1 infection in caucasian individuals bearing mutant alleles of the CCR5 chemokine receptor gene. Nature, 332, 722-725. 
32. Drábek, J., Petřek, M. (1998) 32 bp deletion in CCR-5 gene and human immunodeficiency virus epidemic in the Czech republic. Acta Virol., 42, 121-122.

33. Quillent, C., Oberlin, E., Braun, J., Rousset, D., GonzalezCanali, G., Metais, P., Montagnier, L., Virelizier, J. L., ArenzanaSeisdedos, F., Beretta, A. (1998) HIV-1 resistance phenotype conferred by combination of two separate inherited mutations of CCR5 gene. Lancet, 351, 14-18.

34. Smith, M. W., Dean, M., Carrington, M., Winkler, C., Huttley, G. A., Lomb, D. A., Goedert, J. J., O’Brien, T. R., Jacobson, L. P., Kaslow, R., Buchbinder, S., Vittinghoff, E., Vlahov, D., Hoots, K., Hilgartner, M. W., O’Brien, S. J. (1997) Contrasting genetic influence of CCR2 and CCR5 variants on HIV-1 infection and disease progression. Hemophilia Growth and Development Study (HGDS), Multicenter AIDS Cohort Study (MACS), Multicenter Hemophilia Cohort Study (MHCS), San Francisco City Cohort (SFCC), ALIVE Study. Science, 277, 959-965.

35. Kostrikis, L. G., Huang, Y., Moore, J. P., Wolinsky, S. M., Zhang, L., Guo, Y., Deutsch, L., Phair, J., Neumann, A. U., Ho, D. D. (1998) A chemokine receptor CCR2 allele delays HIV-1 disease progression and is associated with a CCR5 promoter mutation. Nat. Med., 4, 350-353.

36. McDermott, D. A., Zimmerman, P. A., Guignard, F., Kleeberger, C. A., Leitman, S. F., Murphy, P. M. (1998) CCR5 promoter polymorphism affect HIV-1 disease progression. Lancet, 352, 866-870.

37. Easterbrook, P. J., Rostron, T., Ives, N., Troop, M., Gazzard, B G., Rowland-Jones, S. L. (1999) Chemokine receptor polymorphisms and Human Immunodeficiency Virus disease Progression. J. Infec. Dis., 180, 1096-1105.

38. Hall, I. P., Wheatley, A., Christie, G., McDougall, C., Hubbard, R., Helms, P. J. (1999) Association of CCR5 332 with reduced risk of asthma. Lancet, 354, 1264-1265.

39. Szalai, C., Bojszkó, Á., Beko, G., Falus, A. (2000) Prevalence of CCR5832 in allergic diseases. Lancet, 355, 66.

40. Petřek, M., Drábek, J., Kolek, V., Zlámal, J., Welsh, K. I., Bunce, M., Weigl, E., Du Bois, R. M. (2000) CC chemokine receptor gene polymorphisms in Czech patients with pulmonary sarcoidosis. Am. J. Respir. Crit. Care. Med., 162, 1000-1003.

41. Hizawa, N., Yamaguchi, E., Furuya, K., Jinushi, E., Ito, A., Kawakami, Y. (1999) The role of the CC chemokine receptor 2 gene polymorphism V64I (CCR2-64I) in sarcoidosis in a Japanese population. Am. J. Respir. Crit. Care. Med., 159, 20212023.

42. Bennetts, B. H., Teutsch, S. M., Buhler, M. M., Heard, R. N. S., Stewart, G. J. (1997) The CCR5 deletion mutation fails to protect against multiple sclerosis. Hum. Immunol., 58, 52-59.

43. Szalai, C., Császár, A., Czinner, A., Szabó, T., Pánczél, P., Madácsy, L., Falus, A. (1999) Chemokine receptor CCR2 and CCR5 polymorphisms in children with insulin-dependent diabetes mellitus. Pediatr. Res., 46, 82-84.

44. Gómez-Reino, J. J., Pablos, J. L., Carreira, P. E., Santiago, B., Serrano, L., Vicario, J. L., Balsa, A., Figueroa, M., De Juan, M. D. (1999) Association of rheumatoid arthritis with a functional chemokine receptor. Arthritis Rheum., 42, 989-992.

45. Cooke, S. P., Forrest, G., Venables, P. J. W., Hajeer, A. (1998) The $\delta 32$ deletion of CCR5 receptor in rheumatoid arthritis. Arthritis Rheum., 41, 1135-1136.

46. Mack, M., Bruhl, H., Gruber, R., Jaeger, C., Cihak, J., Eiter, V., Plachý, J., Stangassinger, M., Uhlig, K., Schattenkirchner, M., Schlondorff, D. (1999) Predominance of mononuclear cells expressing the chemokine receptor CCR5 in synovial effusions of patients with different forms of arthritis. Arthritis Rheum., 42, 981-988.

47. Renzoni, E., Lympany, P., Sestini, P., Pantelidis, P., Wells, A., Black, C., Welsh, K., Bunn, C., Knight, C., Foley, P., Du Bois, R. M. (2000) Distribution of novel polymorphisms of the interleukin- 8 and CXC receptor 1 and 2 genes in systemic sclerosis and cryptogenic fibrosing alveolitis. Arthritis Rheum., 43, 1633-40.

48. Cacalano, G., Lee, J., Kikly, K., Ryan, A. M., Pitts-Meek, S., Hultgren, B., Wood, W. I., Moore, M. W. (1994) Neutrophil and B-cell expansion in mice that lack the murine IL-8 receptor homolog. Science, 265, 682-684.
49. Hancock, W. W. (1999) Therapeutic approaches to induction of allograft tolerance based on modulation of select chemokines and chemokine receptors. Eur. Cytokine Netw., 10, 101-104.

50. Nagasawa, T., Hirota, S., Tachibana K., Takakura, N., Nishikawa, S., Kitamura, Y. (1996) Defects of B-cell lymphopoiesis and bone-marrow myelopoiesis in mice lacking the CXC chemokine PBSF/SDF-1. Nature, 382, 635-638.

51. Zou, Y. R., Kottmann, A. H., Kuroda, M., Taniuchi, I., Littman, D. R. (1998) Function of the chemokine receptor CXCR4 in haematopoiesis and in cerebellar development. Nature, 393, 595-599.

52. Tachibana, K., Hirota, S., Iizasa, H., Yoshida, H., Kawabata, K., Kataoka, Y., Matsushima, K., Yoshida, N., Nishikawa, S., Kishimoto, T., Nagasawa, T. (1998) The chemokine receptor CXCR4 is essential for vascularization of the gastrointestinal tract. $\mathrm{Na}$ ture, 393, 591-599.

53. Forster, R., Mattis, A. E., Kremmer, E., Wolf, E., Brem, G., Lipp, M. (1996) A putative chemokine receptor, BLR1, directs B cell migration to defined lymphoid organs and specific anatomic compartments of the spleen. Cell, 87, 1037-1047.

54. Gao, J. L., Wynn, T. A., Chang, Y., Lee, E. J., Broxmeyer, H. E., Cooper, S., Tiffany, H. L., Westphal, H., Kwon, C. J., Murphy, P. M. (1997) Impaired host defense, hemathopoiesis, granulomatous inflammation and type 1 - type 2 cytokine balance in mice lacking CC chemokine receptor 1. J. Exp. Med., 185, 1959-1968.

55. Gerard, C., Frossard, J. L., Bhatia, M., Saluja, A., Gerard, N. P., Lu, B., Steer, M. (1997) Targeted disruption of the betachemokine receptor CCR1 protects against pancreatitis-associated lung injury. J. Clin. Invest., 100, 2022-2027.

56. Topham, P. S., Csizmadia, V., Soler, D., Hines, D., Gerard, C. J., Salant, D. J., Hancock, W. W. (1999) Lack of chemokine receptor CCR1 enhances Th1 responses and glomerular injury during nephrotoxic nephritis. J. Clin. Invest., 104, 1549-1557.

57. Gao, W., Topham, P. S., King, J. A., Smiley, S. T., Csizmadia, V., Lu, B., Gerard, C. J., Hancock, W. W. (2000) Targeting of the chemokine receptor CCR1 suppresses development of acute and chronic cardiac allograft rejection. J. Clin. Invest., 105, 3544.

58. Boring, L., Gosling, J., Chensue, S.,W., Kunkel, S. L., Farese, R. V., Broxmeyer, H. E., Charo, I. F. (1997) Impaired monocyte migration and reduced type 1 (Th1) cytokine responses in C-C chemokine receptor 2 knockout mice. J. Clin. Invest., 100, 2552-2561.

59. Kurihara, T., Ward, G., Loy, J., Bravo, R.. (1997) Defects in macrophage recruitment and host defense in mice lacking the CCR2 chemokine receptor. J. Exp. Med., 186, 1757-62.

60. Boring, L., Gosling, J., Cleary, M., Charo, I. F. (1998) Decreased lesion formation in CCR2-/- mice reveals a role for chemokine in the initiation of atherosclerosis. Nature, 394, 894-897.

61. Zhou, Y., Kurihara, T., Ryseck, R. O., Yang, Y., Ryan, C., Loy, J., Warr, G., Bravo, R. (1998) Impaired macrophage function and enhanced $\mathrm{T}$ cell-dependent immune response in mice lacking CCR5, the mouse homologue of major HIV-1 coreceptor. J. Immunol., 160, 4018-4025.

62. Forster, R., Schubel, A., Breitfeld, D., Kremmer, E., RennerMuller, I., Wolf, E., Lipp, M. (1999) CCR7 coordinates the primary immune response by establishing functional microenvironments in secondary lymphoid organs. Cell, 99, 23-33.

63. Horuk, R. (1994) The interleukin-8-receptor family: from chemokines to malaria. Immunol. Today, 15, 169-174.

64. Tournamille, C., Colin, Y., Carton, J. P., Van Kim, C. (1995) Disruption of a GATA monofit in the Duffy gene promoter abolishes erythroid gene expression in Duffy-negative individuals. Nat. Genet., 10, 224-228.

65. Gutierrez-Ramos, J. C. (1999) The coordinated action of chemokines in the lung orchestrates lung inflammation and bronchial hyperresponsiveness during asthma. Eur. Cytokine Netw., 10, 277-278.

66. Ponath, P. D., Qin, S., Post, T. W., Wang, J., Wu, L., Gerard, N. P., Newman, W., Gerard, C., Mackay, C. R. (1996) Molecular cloning and characterization of a human eotaxin receptor expressed selectively on eosinophils. J. Exp. Med., 183, 2437-2448. 
67. Uguccioni, M., Mackay, C. R., Ochensberger, B., Loetscher, P., Rhis, S., LaRosa, G. J., Rao, P., Ponath, P. D., Baggiolini, M., Dahinden, C. A. (1997) High expression of the chemokine receptor CCR3 in human blood basophils. Role in activation by eotaxin, MCP-4, and other chemokines. J. Clin. Invest., 100, $1137-1143$.

68. Power, C.A. (1999) Effects of CCR4 knockout in a mouse model of lung inflammation. Eur. Cytokine Netw., 10, 296-297.

69. Fraziano, M., Cappelli, G., Santucci, M., Mariani, F., Amicosante, M., Casarini, M., Giosue, S., Bisetti, A., Colizzi, V. (1999) Expression of CCR5 is increased in human monocyte-derived macrophages and alveolar macrophages in the course of in vivo and in vitro Mycobacterium tuberculosis infection. AIDS Res. Hum. Retroviruses, 15, 869-874.

70. Carramolino, L., Kremer, L., Goya, I., Varona, R., Buesa, J. M., Gutierrez, J., Zaballos, A., Martinez-A, C., Marquez, G. (1999) Down-regulation of the beta-chemokine receptor CCR6 in dendritic cells mediated by TNF-alpha and IL-4. J. Leukoc. Biol., $66,837-844$.

71. Lipp, M. (1999) Navigation of lymphocyte subsets by the chemokine system. Eur. Cytokine Netw. 10, 265-266.

72. Folkesson, H. G., Mathay, M. A., Hebert, C. A., Broaddus V. C. (1995) Acid-aspiration induced lung injury in rabbits is mediated by interleukin-8-dependent mechanisms. J. Clin. Invest., 96, 107-116.

73. Sekido, N., Mukaida, N., Harada, A., Nakanishi, I., Watanabe, Y., Matsushima, K. (1993) Prevention of lung reperfusion injury in rabbits by a monoclonal antibody against interleukin-8. Nature, 365, 654-657.

74. Matsumoto, T., Yokoi, K., Mukaida, N., Harada, A., Yamashita, J., Watanabe, Y., Matsuchima, K. (1997) Pivotal role of interleukin-8 in the acute respiratory distress syndrome and cerebral reperfusion injury. J. Leukoc. Biol., 62, 581-587.

75. Zagorski, J., Wahl, S. M. (1997) Inhibition of acute peritoneal inflammation in rats by a cytokine induced neutrophil chemoattractant receptor antagonist. J. Immunol., 159, 1059-1062.

76. Sorensen, T. L., Tani, M., Jensen, J., Pierce, V., Lucchinetti, C., Folcik, V. A., Qin, S., Rottman, J., Sellebjerg, F., Strieter, R. M., Frederiksen, J. L., Ransohoff, R. M. (1999) Expression of specific chemokines and chemokine receptors in the central nervous system of multiple sclerosis patients. J. Clin. Invest., 103, 807-815.

77. Donzella, G. A., Schols, D., Lin, S. W., Esté, J. A., Nagashima, K. A., Maddon, P. J., Allaway, G. P., Sakmar, T. P., Henson, G., De Clercq, E., Moore, J. P. (1998) AMD3100, a small molecule inhibitor of HIV-1 entry via the CXCR4 co-receptor. Nat. Med., 4, 72-77.

78. White, J. H., Wise, A., Main, M. J., Green, A., Fraser, N. J., Disney, G. H., Barnes, A. A., Emson, P., Foord, S. M., Marshall, F. H. (1998) Heterodimerization is required for the formation of a functional GABA(B) receptor. Nature, 396, 679-682.
79. De Clercq, E. (1999) Inhibition of HIV infection by bicyclams, highly potent and specific CXCR4 antagonists. Eur. Cytokine Netw., 10, 281-285.

80. Lloyd, C. M., Minto, A. W., Dorf, M. E., Proudfoot, A. E. I., Wells, T. N. C., Salant, D. J., Gutierrez-Ramos, J. C. (1997) RANTES and monocyte chemoattractant protein 1 (MCP-1) play an important role in the inflammatory phase of crescentic nephritis, but only MCP-1 is involved in crescent formation and interstitial fibrosis. J. Exp. Med., 185, 1371-1380.

81. Gu, L., Okada, Y., Clinton, S. K., Gerard, C., Skhova, G. K., Libby, P., Rollins, B. J. (1998) Absence of monocyte chemoattractant protein-1 reduces atherosclerosis in low density lipoprotein receptor-deficient mice. Mol. Cell, 27, 275-281.

82. Proudfoot, A. E. I., Power, C. A., Hoogewerf, A. J., Montjovent, M. O., Borlat, F., Offord, R. E., Wells, T. N. C. (1996) Extension of recombinant human RANTES by the retention of the initiating methionine produces a potent antagonist. J. Biol. Chem., 271, 2599-2603.

83. Ying, S., Robinson, D. S., Meng, Q., Rottman, J., Kennedy, R., Ringler, D. J., Mackay, C. R., Daugherty, B. L., Springer, M. S., Durham, S. R., Williams, T. J., Kay, A. B. (1997) Enhanced expression of eotaxin and CCR3 mRNA and protein in atopic asthma. Association with airway hyperresponsiveness and predominant co-localisation of eotaxin mRNA to bronchial epithelial and endothelial cells. Eur. J. Immunol., 27, 3507-3516.

84. Gonzalo, J. A., Lloyd, C. M., Kremer, J. Finger, E., Martinez, A. C., Siegelman, M. H., Cybulsky, M., Gutierrez-Ramos, J. C. (1996) Eosinophil recruitment to the lung in a murine model of allergic inflammation. The role of T-cells, chemokines and adhesion receptors. J. Clin. Invest., 98, 2332-2345.

85. Rothenberg, M. E., Mac Lean, J. A., Pearlman, E., Luster, A. D., Leder, P. (1997) Targeted disruption of the chemokine eotaxin partially reduces antigen-induced tissue eosinophilia. J. Exp. Med., 185, 785-790.

86. Gonzalo, J. A., Lloyd, C. M., Wen, D., Albar, J. P., Wells, T. N. C., Proudfoot, A., Martinez, A. C., Dorf, M., Bjerke, T., Coyle, A. J., Gutierrez-Ramos, J. C. (1998) The coordinated action of $\mathrm{CC}$ chemokines in the lung orchestrates allergic inflammation and airway hyperresponsiveness. J. Exp. Med., 188, 157-167.

87. Oppenheim, J. J., Zachariae, C. O. C., Mukaida, N., Matsushima, K. (1991) Properties of the novel proinflammatory supergene "intercrine" cytokine family. Annu. Rev. Immunol., 9, 617-648.

88. Petřek, M., Du Bois, R. M., Śírová, M., Weigl, E. (1995) Chemotactic cytokines (chemokines) and their role in physiological and immunopathological reactions. Folia Biol., 41, 263-283.

89. McFadden, G., Kelvin, D. (1997) New strategies for chemokine inhibition and modulation: you take the high road and I'll take the low road. Biochem. Pharmacol., 54, 1271-1280.

90. Schwarz, M. K., Wells, T. N. C. (1999) Interfering with chemokine networks - the hope for new therapeutics. Curr. Opin. Chem. Biol., 3, 407-417. 